\title{
Sedimentological Study of Caves in the Zemo Imereti Plateau, Georgia, Caucasus Region
}

\author{
Lasha Asanidze ${ }^{1}$, Nino Chikhradze ${ }^{1,2}$, Zaza Lezhava1, Kukuri Tsikarishvili' ${ }^{1}$, Jason Polk³, \\ Giorgi Chartolani ${ }^{1}$
}

${ }^{1}$ Vakhushti Bagrationi institute of Geography, Ivane Javakhishvili Tbilisi State University, Department of Geomorphology, Tbilisi, Georgia

${ }^{2}$ School of Natural Sciences and Engineering, Ilia State University, Tbilisi, Georgia

${ }^{3}$ Center for Human Geo Environmental Studies, Department of Geography and Geology, Western Kentucky University, Kentucky, USA

Email: *lasha.asanidze@tsu.ge

How to cite this paper: Asanidze, L., Chikhradze, N., Lezhava, Z., Tsikarishvili, K., Polk, J. and Chartolani, G. (2017) Sedimentological Study of Caves in the Zemo Imereti Plateau, Georgia, Caucasus Region. Open Journal of Geology, 7, 465-477. https://doi.org/10.4236/ojg.2017.74032

Received: February 17, 2017

Accepted: April 17, 2017

Published: April 20, 2017

Copyright $\odot 2017$ by authors and Scientific Research Publishing Inc. This work is licensed under the Creative Commons Attribution International License (CC BY 4.0).

http://creativecommons.org/licenses/by/4.0/

\begin{abstract}
The Zemo Imereti Plateau is located in the easternmost part of the limestone region of western Georgia and is Caucasus' only karst plateau. It is centrally located in a relatively elevated part of the intermountain plain of the country of Georgia. Lithostratigraphical (petrographic, mineralogical, and XRD) research on terrigenous sediments found in caves in the region was conducted in the Upper Cretaceous limestones located at different hypsometric levels (400- $700 \mathrm{~m}$ ). This study focused on allochthonous deposits, which, due to sedimentological features, contains significant and complete information for paleogeographic reconstruction as opposed to the autochthonous sediments. Source provinces of the sediments' origin were determined using petrographic analysis. Lithological study of the terrigenous sediments indicated their origin from the Racha range, as well as their transportation mechanisms, and sedimentation conditions during deposition. Approximate ages (the end of the Middle Pleistocene and the beginning of the Late Pleistocene) of ancient terrestrial sediments in Rganisklde Cave were achieved by taking into account the geological and geomorphological development of the region. Lithostratigraphical analysis of the cave deposits and modern archaeological data indicate that the formation of the caves in the Zemo Imereti plateau took place mainly during the end of the Middle Pleistocene and in the beginning of the Pleistocene; while on the southern slope of the Racha range and in the surrounding area of Ertso-Tsona (Caucasus southern slope), they formed in the Early Pleistocene.
\end{abstract}

\section{Keywords}

Terrigenous Sediments, Geomorphologic Evolution, Zemo Imereti Plateau, Georgia 


\section{Introduction}

In Georgia, karst is represented only western part of the country. The limestone massifs occupy $4475 \mathrm{~km}^{2}$ of the entire territory of Georgia [1] [2], which includes over 1500 known caves.

General information about evolution and the maximum age of caves formed in Georgia's limestone regions is generalized, and of limited detail, e.g., [3] [4] [5] [6]. The formation and evolution of these karst features is complex and still poorly understood, with disagreement about their exact timing and development still underway. This study aims to provide additional data about the geomorphic evolution of the caves in the region by providing some of the first sedimentological and geological contextualization for several prominent caves.

Paleontological, palynological, and archaeological surveys allow only approximate estimates of minimum age of cave development, but lack data about their origin and age of inception. The cultural layers' present in caves, though, are significant with respect to understanding their evolution and should be considered the period of time from deposition of the terrigenous sediments in the cave by the streams to the complete disappearance of the streams, after which the accumulation of cultural layers takes place [7] [8]. The aforementioned period covers a significant part of the geological epoch and includes some evidence of the cave development and subsequent usage by humans [9] [10].

Secluded and protected areas can be found in caves, where the terrigenous sediments accumulate continuously from conception to present day or, at least, the ancient sediments are preserved. If certain sediment deposits in the caves are sampled and the age of the deposits is identified, then it is possible to better estimate the minimum age of cave formation. Cave sediments can also provide insight to the geomorphologic evolution, processes, and hydrology influencing cave development and the myriad changes underway in the landscape that are preserved in the cave sediment record [11] [12]. In certain cases, allogenic sediments can be useful for determining the transport and fate of source materials over long distances under varying climatic conditions, while further insight to past drainage patterns and the weathering of rock layers no longer present in the stratigraphic column may also be revealed from sediment deposits in caves that span geologic time in their deposition and preservation [13] [14].

The study of the terrigenous sediments also allows determining the process and accumulation rates of cave sedimentation and to generally reconstruct the paleogeographic history and geomorphologic development of the region [15]. Sediments in caves can accurately provide a record of climatic and anthropogenic influences, as well as a record of precipitation and runoff through the use of radiogenic dating $\left({ }^{14} \mathrm{C}\right.$, Cs-137) of the sediment sequence, combined with other proxy isotope, physical, and accumulation data [16] [17].

The aims of this research were to: 1) identify source areas of terrigenous sediments and transportation mechanisms of sediments in Georgia in the Zemo Imereti plateau's caves and 2) to explain features and processes of the sedimentation in the caves based on lithological information taking into account the pa- 
leogeographic history of the region. In this capacity, a lithological survey was conducted on the terrigenous sediments of Zemo Imereti plateau's caves, which were not previously studied in this manner to determine their paleogeography and geomorphology.

\section{Study Area}

The Zemo Imereti plateau covers the easternmost part of the limestone zone of western Georgia, which is characterized by unique natural conditions (relief, tectonics, climate, surface and ground waters) and is the only platform karst region in the Caucasus. The geological structure controls the main morphological features of the study region. It is the most elevated part of Georgia's tectonic plate, though the contemporary plasticity of the relief is substantially altered due to exogenic processes and tectonic impacts. Many individual features characterize the relief of the plateau. Only in Georgia can there be found a significantly elevated relief of the denudation-structure, plateau-like surfaces with layers of inactive, tectonically resilient layers of rock. The region of this study is geologically and structurally, as part of the Georgia's tectonic plate, composed of two structural floors-the pre-Cretaceous basement massif and the Cretaceous-Neo gene platform cover.

The study area is a central, relatively elevated part of the intermountain plain of Georgia. Morphologically, the Zemo Imereti karst region is a structural plateau [18]. Its relief is gentle to the surface and is dissected by the deep (100 - 300 m) canyon-like gorges of the Kvirila, Dzirula, and Sadzalikhevi rivers and their tributaries, that intersect the thick, layered limestones of the Turonian-Danish horizontal unit. The canyon-like gorges cause the fragmentation of the structural plateau into several small plateaus, the relative heights of which range within 100 - 300 meters, while the absolute heights are 500 - 800 meters above sea level (Figure 1).

The Zemo Imereti plateau, with its gorges, is a classic example of fragmented relief topography, and influences the intensity of the karst processes and formation of morphological characteristics of the karst features, as the evolution of the fissure-karst waters hydrodynamic zones and caves was going on the background of the vertical cutting of the plateau surface and accordingly, gradual lowering of the erosion basis. This is clearly evidenced by the fact that the entrances of the caves open on the slopes of the river gorges and often are located at different reliefs from the river thalwegs [20]. The Plateau is rich in underground karst waters. Vadose springs flow out from the riverbeds at different elevations and their discharges fluctuate within $0.1-10 \mathrm{~L} / \mathrm{s}$. The significant discharge sources $(50-300 \mathrm{~L} / \mathrm{s})$ are related to the seasonal fluctuation of the baselevel and phreatic zone [20].

Zemo Imereti plateau is located on the eastern periphery of the Colchis humid subtropical zone and almost all year is provided with the abundant precipitation. The highest amount of winter precipitation falls in the form of rain. The balance of the annual runoff is positive everywhere, which is sufficient to maintain active 


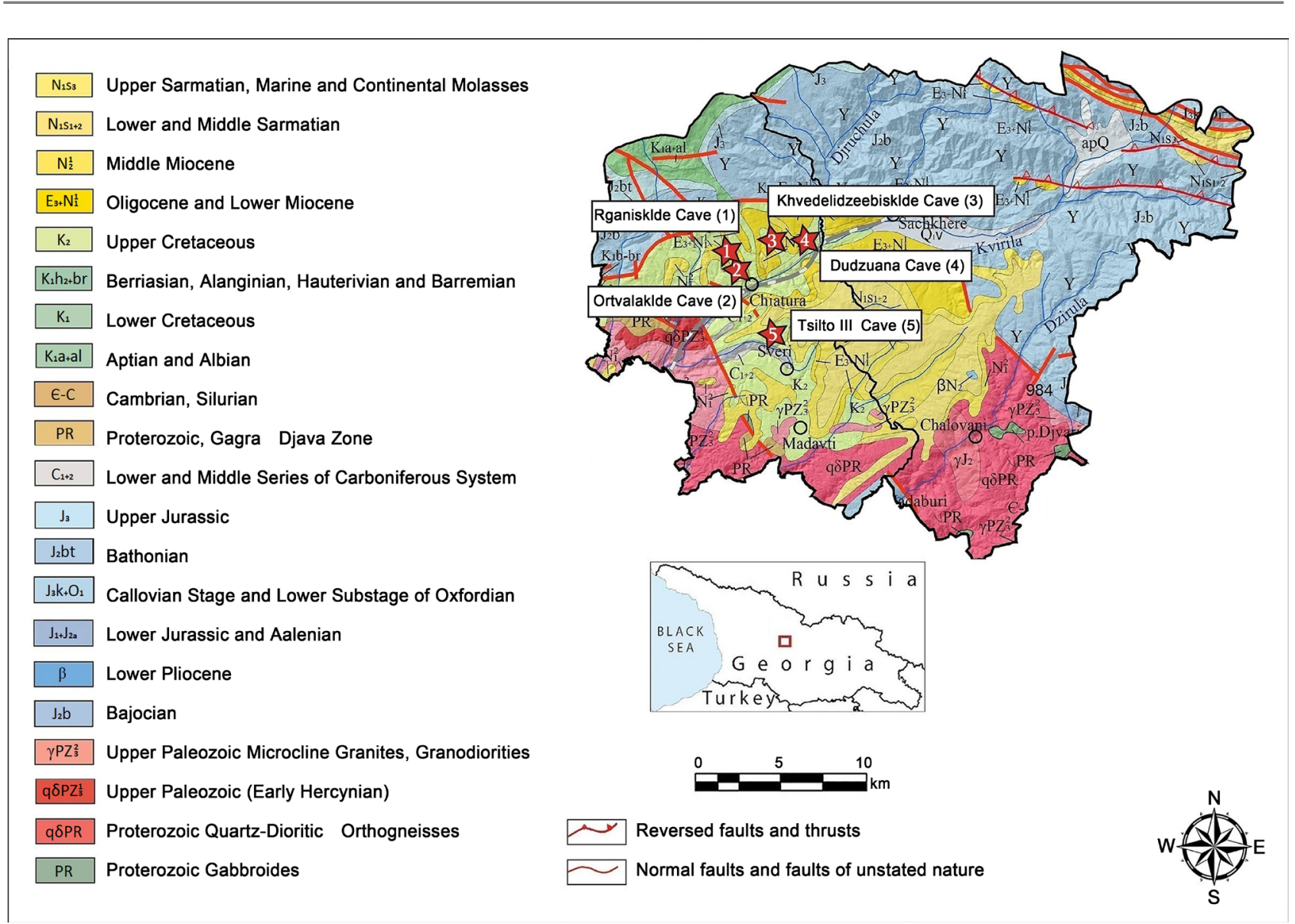

Figure 1. A geological map of the study area (red box on inset) zoomed in to show the geological complexity as well as the topographic relief in which the karst plateau is located [19].

karst processes throughout the year, especially during the cold season. Summer temperatures average $22^{\circ} \mathrm{C}$ and winter temperatures around $3^{\circ} \mathrm{C}$, with rainfall averaging 500 to $800 \mathrm{~mm}$ per year [20].

The study area is located within the vertical (epigenetic) uplifted zone, which was not continuous over time in the past, but persisted through less tectonically active periods. Here, the caves of the various stages of evolution are located in four to five tiers. Primitive human dwellings were discovered in about 20 caves in Zemo Imereti and the surrounding area; among them are the Early Paleolithic caves, which include Acheul-Moustier (Tsona cave) and Moustier (Jruchula and Ortvalaklde), and the Late Paleolithic caves, which include Deviskhvreli, Mghvimevi, Samertskhleklde, Dzudzuana, Gvarjilasklde, Sareki, and Shvalieti), and many epipaleolithic dwellings. In some cave, the cultural layers reach three to six $\mathrm{m}$ in thickness. The cultural layer is located on the terrigenous sediments and often the latter are washed away and missing from the sequence between the cultural layer and the bedrock.

\section{Materials and Methods}

For this study, three caves were selected at different elevations: Rganisklde Cave (absolute height $740 \mathrm{~m}$ above sea level, relative height 80 - $90 \mathrm{~m}$ ); Khvedelidzee- 


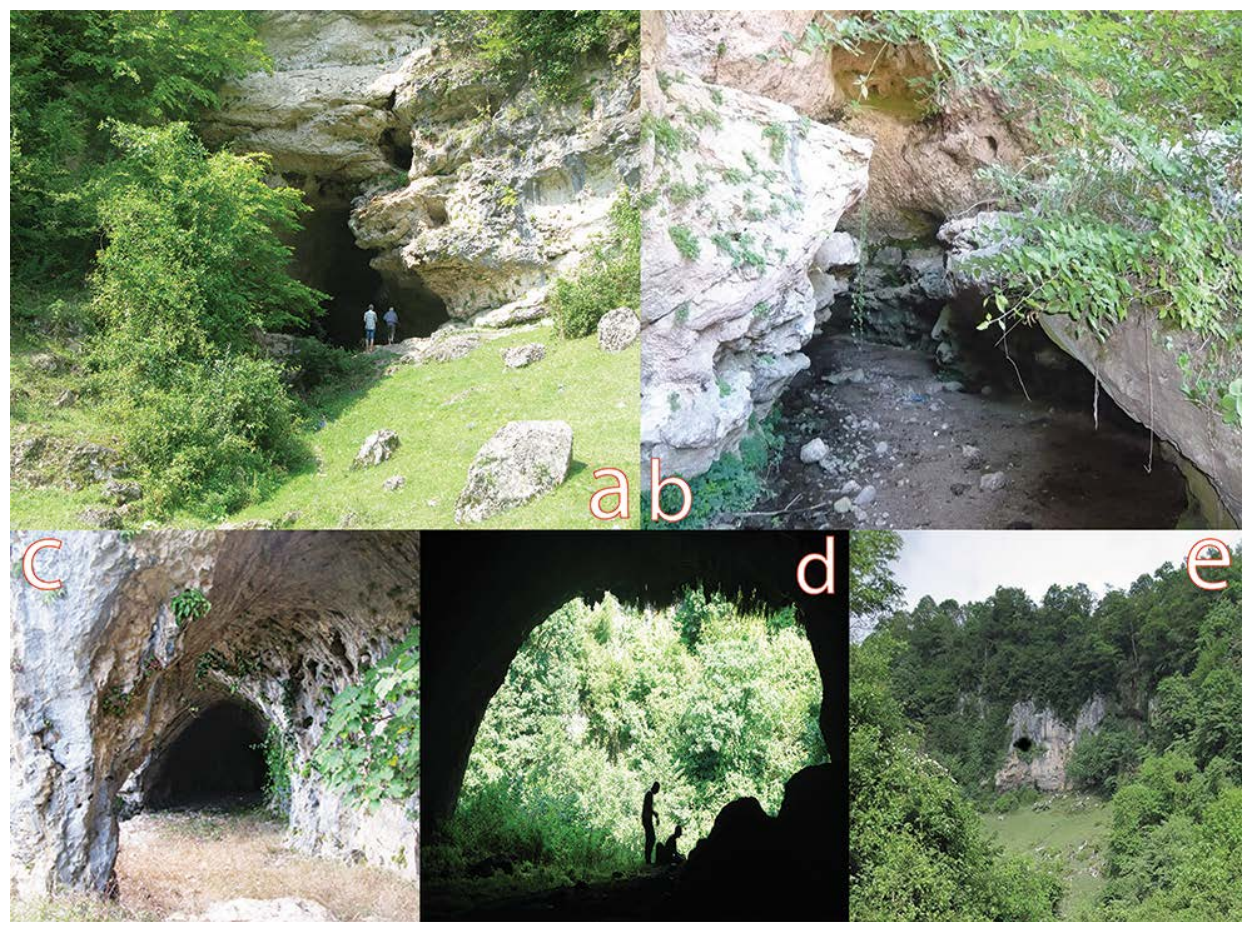

Figure 2. (a) Entrance to Khvedelidzeebisklde Cave; (b) One of the entrances to Tsilto III Cave (view from the inside); (c) The Ortvalaklde Cave entrance; (d) The Dzudzuana Cave entrance; (e) The Rganisklde Cave entrance.

bisklde Cave (absolute height $415 \mathrm{~m}$ above sea level, relative height 3.5 meters); and Tsilto III Cave (absolute height $620 \mathrm{~m}$ above sea level, relative height 90 100 meters). Each cave underwent lithostratigraphic, geochemical, and XRD analysis (Figure 2). All of those samples were powder and have been measured by two different types of instruments, which are: X-ray Diffractometry (XRD), and Scanning Electron Microscopy (SEM). Thus, standard methods of X-ray and SEM analysis were used.

Profiles were cut into the terrigenous sediments in each cave to the bedrock, which allowed for study of the entire sedimentary sequence. At Rganisklde Cave, two sediment profiles were analyzed, with one located at the entrance and the second 50 meters away from the entrance.

Among the layers, the lenses, concretions, and inclusions were singled out and described. Samples were taken from the cave walls (at different levels) in order to identify the genesis of shingly clays. The quality of the presence of psephitic inclusions in the terrigenous material was assessed by the Khabakov five-point system [21]. In order to identify the source areas of the terrigenous sediments in the caves, petrographic analysis of the psephitic material was completed on the profiles of the sediments collected, as well as geochemical and XRD analysis of aleurolitic-pelite materials. Comparisons were made with the various sediment layers within the three caves to the potential parent sources materials in the region to determine their origin. The cave's evolution was determined based on the sediment characteristics and its context with nearby cultural layers and known periods of sedimentation. 


\section{Results and Discussion}

As already noted, two sediment profiles were analyzed in Rganisklde Cave at the entrance and 50 meters away from the entrance. The sediment profile at the entrance is $70 \mathrm{~cm}$ thick and consists of four different layers (Figure 3 ).

The first layer (characterizing the layers from bottom to the top) is $18 \mathrm{~cm}$ of thick orange clays, followed by $2 \mathrm{~cm}$ thick layer of fine-grained, dark orange clay. The second layer is represented by $25-30 \mathrm{~cm}$ thick, mostly well-processed alluvium (medium sizes of $5-6 \mathrm{~cm}$ diameter). Individual inclusions of larger sizes (diameter of $15 \mathrm{~cm}$ ) are found in the form of well-sorted cobbles. The filler is represented by clay, which is $10 \%-15 \%$ of the entire layer. The same layer contains a $2-3 \mathrm{~cm}$ thick middle layer of manganese clay. The third layer is composed of gray clays (12 cm thick), and brownish lenses without inclusions. The fourth layer contains dark gray clays up to $25 \mathrm{~cm}$ in thickness. Raw limestone gravel inclusions are present, along with charcoal or black organic carbon inclusions.

In Rganisklde Cave, the excavated profile 50 meters away from the entrance contains deposits $160 \mathrm{~cm}$ thick in three distinct layers. The first layer (surface to $80 \mathrm{~cm}$ below) is comprised of khaki colored, fine-grained clays without inclusions. Here, four samples were taken: oneat the bottom of the layer, the second $40 \mathrm{~cm}$ from the bottom, the third at $80 \mathrm{~cm}$ from the bottom (in the contact zone), and the fourth from the area at $60 \mathrm{~cm}$ from the bottom. The second layer is brown loam and composed of clastic and angular limestone pieces, which are not sorted. It is slightly weathered material and found in $80 \%-85 \%$ of the

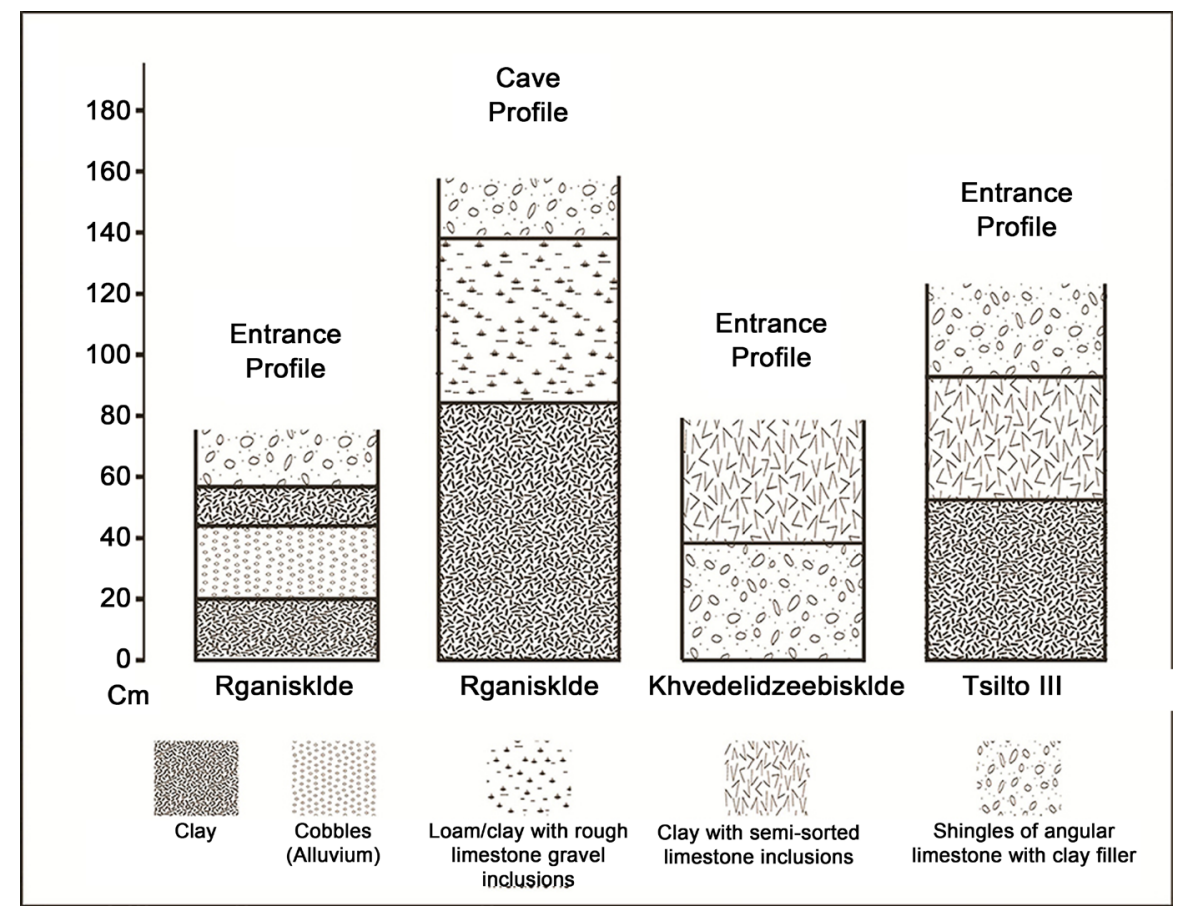

Figure 3. Lithological profiles of sediments from the three studied caves indicating the stratigraphic depths and characteristics of the sediment sequences for Rganisklde, Khvedelidzeebisklde, and Tsilto III caves. 
entire layer. Loam plays the role of filler. The third layer is comprised of a $25 \mathrm{~cm}$ thick dark brown loam with small inclusions of weathered rock. Small manganese concretions are present.

In the front part of Khvedelidzeebisklde Cave an $84 \mathrm{~cm}$ deep profile was taken, where two layers were distinguished. The first is represented by brownishgray clays and poorly sorted limestone rock inclusions $(4 \%-5 \%$ of the whole layer), while the second layer includes blackish clays (coloring is casued by marganese) with slightly sorted limestone pieces ( $10 \%$ of the whole layer), and small size manganese concretions ( $1-1.5 \mathrm{~mm}$ ).

One sediment profile was taken at the entrance of Tsilto III Cave (Figure 2(b)). Its depth was $130 \mathrm{~cm}$ and three layers were identified. One sample was collected from each layer. The first layer is comprised of $52 \mathrm{~cm}$ of brow (orange) clays, in which the black colored manganese middle layer is clearly distinguished. The second layer ( $40 \mathrm{~cm}$ thick) is mainly comprised of gray clays. Manganese concretions and clay lens inclusions are present, as well as limestone pieces. The latter is slightly sorted and comprises $5 \%-6 \%$ of the whole layer. The third layer is $38 \mathrm{~cm}$ thick and made up of dark gray clays and angular limestone inclusions. The limestone inclusions comprise about $10 \%$ of the whole layer. Here, the black organic carbon inclusions are present as well; therefore, it is presumed to be a cultural layer.

Geochemical analysis of the caves' terrigenous sediments confirmed that the composition of the deposits in the surveyed caves is highly similar. The exception is: 1) a high percentage content of $\mathrm{MnO}$ in the 11th and 12th samples of the Khvedelidzeebisklde Cave deposits, which is caused by manganese deposits in the cave; 2) an increase in the percentage of $\mathrm{P}_{2} \mathrm{O}_{5}$ in the 4th and 7th samples of the Rganisklde Cave deposits is due to the presence of organic waste; and 3) low percentages of $\mathrm{CaO}$ in the 3rd and 6th (Rganisklde), and 11th and 12th (Khvedelidzeebisklde) samples, which is caused by the washing away of $\mathrm{CaO}$ during the sedimentation period of these deposits (Table 1).

XRD analysis of the cave sediments revealed that their mineral composition is not significantly different from each other within the studied caves (Table 1). The only exception is the mineral illite, which can be found in all layers of Rganisklde Cave, and is a product of volcanic rock weathering (Table 2).

Almost every layer of the cave sediments was deposited either in the flowing or still waters, which is confirmed by a sharp contrast between the layers both in color and granulometric composition [22]. Boundaries of the layers deposited in still water are almost horizontal and linear, while the ones deposited in flowing water are irregular. In terms of paleogeography, the Rganisklde Cave is the most important within the study area. The paleogeographical relevance of Rganisklde Cave can be determined by taking into account the region's geological and geomorphological location, as well as the hypsometric location (590 m absolute and $35 \mathrm{~m}$ relative relief) of the Ortvalaklde Cave (Figure 2(c)), which is a known cave dwelling (Mousterian) of primitive humans [23].

It appears that at the end of the Middle Pleistocene and beginning of the Late 
Table 1. The geochemical analysis of the aleuro-pelitic materials in each cave.

\begin{tabular}{|c|c|c|c|c|c|c|c|c|c|c|c|c|c|c|}
\hline $\begin{array}{c}\text { Cave Name } \\
\text { Layer \# }\end{array}$ & \multicolumn{2}{|c|}{ Tsilto III } & \multicolumn{2}{|c|}{$\begin{array}{l}\text { Khvedelidzee- } \\
\text { bisklde }\end{array}$} & \multicolumn{6}{|c|}{$\begin{array}{l}\text { Rganisklde } \\
\text { (Profile in the } 50 \mathrm{~m} \text { from the entry) }\end{array}$} & \multicolumn{4}{|c|}{$\begin{array}{l}\text { Rganisklde } \\
\text { (Profile of the entry) }\end{array}$} \\
\hline Sample \# & 1 & 2 & 3 & 4 & 5 & 6 & 7 & 8 & 9 & 10 & 11 & 12 & 13 & 14 \\
\hline $\mathrm{SiO}_{2}$ & 39.9 & 44.5 & 54.14 & 39.5 & - & 36.57 & - & 39.7 & 41.68 & 37.07 & 56.8 & 48.1 & 61 & 30.1 \\
\hline $\mathrm{Al}_{2} \mathrm{O}_{3}$ & 8.83 & 9.66 & 11.42 & 8.51 & - & 30.08 & - & 15.9 & 10.90 & 12.58 & 13 & 10.2 & 14.5 & 5.97 \\
\hline $\mathrm{Fe}_{2} \mathrm{O}_{3}$ & 14.3 & 5.32 & 6.05 & 3.82 & - & 3.99 & - & 4.30 & 3.97 & 3.95 & 4.3 & 2.47 & 2.49 & 1.93 \\
\hline $\mathrm{TiO}_{2}$ & 0.38 & 0.49 & 0.57 & 0.74 & - & 0.77 & - & 0.35 & 0.37 & 0.46 & 0.5 & 0.30 & 0.56 & 0.18 \\
\hline $\mathrm{MnO}$ & 0.57 & 0.90 & 8.93 & 26.7 & - & 0.09 & - & 0.19 & 0.40 & 0.34 & 0.06 & 0.30 & 0.04 & 0.21 \\
\hline $\mathrm{SO}_{3}$ & 0.05 & 0.04 & 0.40 & 0.15 & - & 0.03 & - & 0.08 & 0.05 & 0.11 & 0.04 & 0.06 & 0.03 & 0.07 \\
\hline $\mathrm{CaO}$ & 17.9 & 17.9 & 2.23 & 2.99 & - & 1.35 & - & 15.4 & 19.16 & 9.26 & 7.31 & 18.9 & 4.95 & 20.5 \\
\hline $\mathrm{MgO}$ & 1.47 & 1.67 & 1.36 & 1.79 & - & 0.45 & - & 1.03 & 1.35 & 1.36 & 1.01 & 1.31 & 1.30 & 2.44 \\
\hline $\mathrm{K}_{2} \mathrm{O}$ & 2.03 & 2.46 & 2.07 & 2.25 & - & 2.11 & - & 2.06 & 2.73 & 2.92 & 5.08 & 3.43 & 4.43 & 2.37 \\
\hline $\mathrm{Na}_{2} \mathrm{O}$ & 0.74 & 0.70 & 0.88 & 0.15 & - & 0.35 & - & 0.37 & 0.89 & 0.55 & 0.75 & 0.58 & 0.41 & 0.37 \\
\hline $\begin{array}{l}\text { Lost by } \\
\text { heating }\end{array}$ & 12.5 & 14.7 & 7.24 & 9.10 & - & 10.40 & - & 16.2 & 15.76 & 10.96 & 8.78 & 12.5 & 7.48 & 23,86 \\
\hline $\mathrm{FeO}$ & 0 & 0 & 0 & 0 & - & 0 & - & 0 & 0 & 0 & 0 & 0 & 0 & 0 \\
\hline Moisture & 1.96 & 1.91 & 4.52 & 4.04 & - & 13.68 & - & 4.14 & 2.64 & 6.20 & 2.06 & 1.10 & 2.64 & 3.98 \\
\hline
\end{tabular}

Table 2. The rentgenostructural analysis of terrigenous sediments.

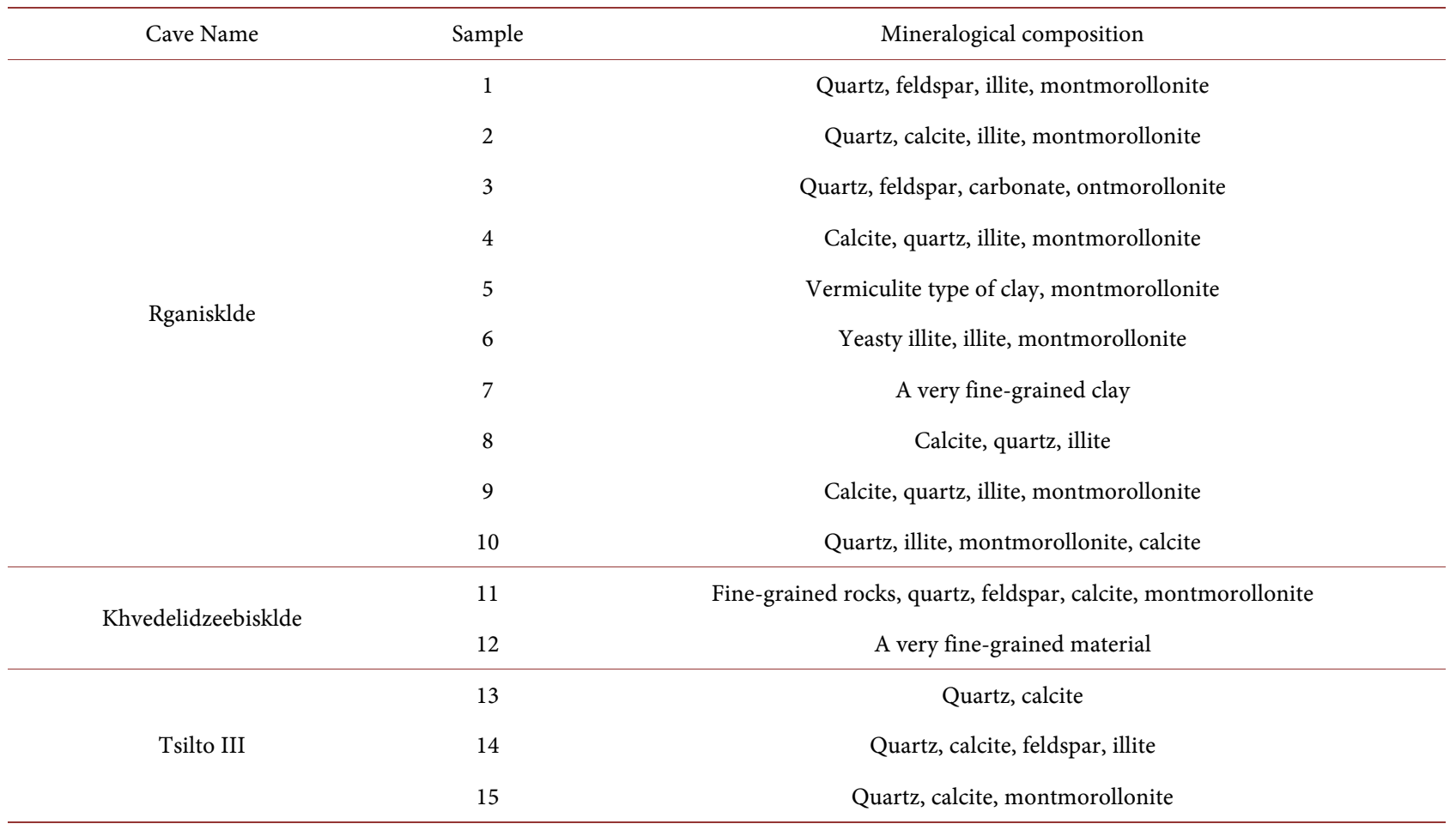


Pleistocene a paleoriver was flowing above Rganisklde Cave, as evidenced by a flat terrace, which is located at an altitude of 100 - 110 meters from Rganisghele bedrock and 25 - 30 meters from the cave. The river alluvium was deposited from the terrace surface of the paleoriver through the karst ponors and fractures. This assumption is confirmed by the petrographic composition of the cobbles in Rganisklde Cave (quartz-porphyry, andesite porphyry, quartz albitophir, quartz sandstone), which were deposited by the river from the Racha range (Jurassic age porphyritic source rock). At that time, the plateau apparently had relatively low hypsometric levels and represented an accumulation area for alluvial sediments derived from the surrounding orographic units (Dzirula-Chkherimela and Likhi ranges, Caucasus, and the Lesser Caucasus).

Such paleomorphologic conditions are justified by the well-rounded cobbles of crystalline rocks found within the paleomorphological hill and valley watersheds of the plateau. The fact that the Racha range southern slope and the karst of the limestone zone, including the caves, of Ertso-Tsona are considerably older than the Zemo Imereti plateau's karst is vividly reflected in the contemporary relief as well. For example, as a result of the high, long-term denudation in the southern slope of the Racha range, any sediment younger than the porphyritic suite (Bajocian) are mostly eroded away and in the Ertso-Tsona area in which the residual limestone relief developed [20].

This is supported by the fact that losing water directly from the bed (the Rganisghele River bed) is still underway [24]. It should be noted that the terraced surfaces are weakly developed in the Chiatura structural plateau, while the paleoriver alluvium in the caves has not yet been found. The paleoriver alluvium found in the Rganisklde Cave contains important information for identifying the evolution, and paleogeographic history of the caves.

Based on the obtained materials, it can be assumed that the action of infiltration caused terrigenous material of considerable thickness to accumulate in the Rrganisklde Cave. Later, when the paleoriver incised deeper and exposed the cave entrance, this material was removed; however, some of the sediments remained in the lower sections. This fact might be the result of highly dense sediments, compacted by cobble fillers and protected by the morphological conditions of the cave.

At the next stage of the cave development, there were dynamic and periodic flows, which are reflected in the sedimentation cycle. The cyclic character of the cave sedimentation is supported by the inclusions of limestone pieces mixed with clays, which are from fragment of cave wall (at various levels, sometimes near the ceiling), as well as new formations on stalactites in fractures. The genesis of the latter can be explained by two processes: a) breaking off the lower parts of stalactites could have happened, because of relatively fast flowing, turbid streams; or, b) the stalactites were hidden in the clay and sand sediments for a long time, then they were eroded by chemical dissolution. Previous work indicates that after removal of sediments from the cave, the speleothem formation was reactivated. Indeed, several stages of new formations can be observed on 
some of the stalactites, which in our view is an indicator of cyclicity of the mentioned processes.

Dzudzuana Cave provides interesting information on the paleogeographical history, because of the cultural layers that were deposited starting directly from the floor of the cave (Figure 2(d)). This is due to the fact that after incision by the river, the entrance of the cave was fully accessible and the primitive human (in the Late Paleolithic) utilized it [7].

As mentioned previously, complete erosion of the sediments within Rganisklde Cave did not take place. From the sediment layer data and morphological features of the cave passages, it can be assumed that the cave was formed at an earlier geological stage than the age of terrigenous sediments utilized in this study. Intensive deposition of these sediments started when the paleoriver was connected with the cave through the conduits and the cave river's discharge was significantly less. In the beginning, it seems, the clay fraction was deposited and after enlargement of the holes the larger fractions were deposited. The study of the stratified sediments in Rganisklde Cave provides the conclusion that the cave already existed by the end of the Middle Pleistocene.

The study of anthropogenic sediments in the caves is of archeological, paleogeographical, and biostratigraphical importance. For example, researchers Kalandadze [25], Liubini [26], and Tsereteli [27], concluded that the deposition of the final part of the Acheul-Moustier and Upper Paleolithic layers (represented by a sterile layer of $70 \mathrm{~cm}$ thick) from the profile of Tsona III Cave's (abs. relief $2100 \mathrm{~m}$ ) anthropogenic sediments is a result of the worsening of weather conditions (occurrence of Riss interglacial and subsequent Wurm glaciation), due to which the high mountain caves (Racha range) became unsuitable for permanent residence. Above the sterile layer are the Mesolithic and Eneolithic layers, which point to the fact that people settled again and lived periodically there. It should be noted that in the caves located in the lower and foothill zones of Zemo Imere$\mathrm{ti}$, which were not influenced by glaciers, these signs are quite obvious, mainly the Late Paleolithic cultural sediments [25].

All of these factors indicate that primitive humans ventured to lower elevations (to the south), because of cooler temperatures and they had to look for a shelter in favorable weather conditions. For example, in Dzudzuana Cave the thickness of the Late Paleolithic cave sediments is equal to 3.5 meters, in Ortvalaklde Cave it is 4 meters thick, and in some places in Jruchula Cave it reaches 6 meters in depth [7]. Deposition of such a thick cultural layers in the Zemo Imereti caves likely started at the end of the Middle Pleistocene or in the beginning of the Late Pleistocene, as during this period several caves (including Rganisklde) already existed.

Future studies of the complex cave sediments may reveal the climatological influence on layers of autochthonous cave sediments, cultural cave sites, and other sites in Zemo Imereti as well. The study of these will clarify the disputes in Anthropocene paleogeography seen in the example of Tsutskhvati cave, where in some debate still exists about the usage of the caves, but more research is needed. 
Collectively, this study provides a first attempt at descriptively characterizing the cave geomorphology and sedimentology of the Zemo Imereti region in an attempt to better understand their importance and role in the karst landscape's evolution with respect to both the physical and cultural paleogeography.

\section{Conclusions}

The lithological study of the terrigenous sediments in caves allowed us to identify their sources (Racha range), transportation modes, and sedimentation conditions. Identification of the age (at the end of the Middle Pleistocene and in the beginning of the Late Pleistocene) of the ancient terrigenous sediments in Rganisklde Cave was determined by taking into account the geological and geomorphological influences of the region.

Lithostratiraphical analysis of the cave deposits and existing archaeological data allowed us to deduce that the formation of the caves in the Zemo Imereti plateau took place mainly during the end of the Middle Pleistocene and the beginning of the Pleistocene, while on the southern slope of the Racha range and in the vicinities of Ertso-Tsona (Caucasus southern slope), formation occurred during the Early Pleistocene. This has implications for better understanding the evolution of the surrounding karst region, the influence of cave usage on ancient human evolution, and the water-rock interactions that formed the region's cave systems.

It should also be noted that a major barrier for our study was the limited financial possibilities, which is why we could conduct the lithostratigraphical (petrographic, mineralogical, and XRD) studies only into some of the caves. In the future, in case of grant projects funding we plan to continue the same type of complex researches in the study region.

\section{Acknowledgements}

We would like to thank sincerely the Shota Rustaveli National Science Foundation for the research funding within the Fundamental Research Grant № FR/218/9-280/13.

\section{References}

[1] Asanidze, L., Tsikarishvili, K. and Bolashvili, N. (2013) Cave Tourism Potential in Georgia. The 2nd International Symposium on Kaz Mountains (Mount Ida) and Edremit, Edremit-Turkey, 3-5 May 2013, 243-247.

[2] Asanidze, L., Tsikarishvili, K. and Bolashvili, N. (2013) Speleology of Georgia. 16th International Congress of Speleology, Vol. 1, Brno, 21-28 July 2013, 29-32.

[3] Maruashvili, L.I. (1963) About the Age of Karst Forms of the Relief of the Greater Caucasus. RASc. SSSR, 151, 904-906. (In Russian)

[4] Kolbutov, A.D. (1961) Geological and Geomorphological Conditions of Localizations of Southern Ossetian Paleolithic Sites. Commission to Study the Quaternary Period. Vol. 18, Publishing House of the USSR Academy of Sciences, Moscow, 109119. (In Russian)

[5] Solovyov, L.N. (1961) About the Age of Karst of the North-Western Caucasus. Coll. 
"Regional Karst Science". Publishing House of the USSR Academy of Sciences, Moscow, 129-135. (In Russian)

[6] Kipiani, S. (1974) Karst of Georgia. Vol. 1, Tbilisi, 350. (In Georgian)

[7] Meshveliani, T.K., Tvalchrelidze, M.G. and Lortkipanidze, D.O. (1990) Cave Dzudzuana-Chronostratigraphy of Paleolithic of Northern, Central and Northern Asia and America. Reports of the International Symposium, Novosibirsk, 231-234. (In Russian)

[8] White, W.B. (2007) Cave Sediments and Paleoclimate. Journal of Cave and Karst Studies, 69, 76-93.

[9] Reidar, L., Ellingsen, K. and Lauritzen, S. (1994) Palaeomagnetic Cave Stratigraphy of Sediments from Hellemofjord, Northen Norway. International Geophysical Journal, 120, 499-515.

[10] Sasowsky, I.D., White, W.B. and Schmidt, V.A. (1995) Determination of StreamIncision Rate in the Appalachian Plateaus by Using Cave-Sediment Magnetostratigraphy. Geology, 23, 415-418. https://doi.org/10.1130/0091-7613(1995)023<0415:DOSIRI >2.3.CO;2

[11] Granger, D.E, Fabel, D. and Palmer, A.N. (2001) Pliocene-Pleistocene Incision of the Green River, Kentucky, Determined from Radioactive Decay of Cosmogenic ${ }^{26} \mathrm{Al}$ and ${ }^{10} \mathrm{Be}$ in Mammoth Cave Sediments. Geological Society of America Bulletin, 113, 825-836. https://doi.org/10.1130/0016-7606(2001)113<0825:PPIOTG>2.0.CO;2

[12] Ford, D.C. and Williams, P.W. (2007) Karst Geomorphology and Hydrology. 2nd Edition, Wiley, West Sussex, 576.

[13] Cordier, D.J. (1998) Sequence Stratigraphy of Siliciclastic Cave Sediments: Depositional Response to a Paleohydrologic Cycle, Western Alachua County, Florida. Thesis, University of Florida, Gainesville, 195.

[14] Farrand, W.R. (2000) Depositional History of Franchthi Cave: Stratigraphy, Sedimentology, and Chronology. Indiana University Press, Indianapolis, 135.

[15] Brinkmann, R. and Reeder, P. (1995) The Relationship between Surface Soils and Cave Sediments: An Example from West Central Florida, USA. Cave and Karst Science, 22, 95-102.

[16] Polk, J.S., van Beynen, P.E. and Reeder, P.E. (2007) Late Holocene Environmental Reconstruction Using Cave Sediments from Belize. Quaternary Research, 68, 53-63.

[17] Polk, J.S., van Beynen, P.E., Asmerom, Y., et al. (2013) Reconstructing past Climate Using Carbon Isotopes from Fulvic Acids in Cave Sediments. Chemical Geology, 360-361, 1-9.

[18] Lezhava, Z., Bolashvili, N., Tsikarishvili, K., Asanidze, L. and Chikhradze, N. (2015) Hydrological and Hydrogeological Characteristics of the Platform Karst (Zemo Imereti Plateau, Georgia). Sinkholes and the Engineering and Environmental Impacts of Karst. Proceedings of the 14th Multidisciplinary Conference, Rochester, 5-9 October 2015, 93-100. https://doi.org/10.5038/9780991000951.1058

[19] Gudjabidze, G.E. (2003) Geological Map of Georgia, Scale 1:500 000. Georgian State Department of Geology and National Oil Company "Saqnavtobi".

[20] Lezhava Z. (2015) The Karst of Zemo Imereti Plateau and Its Surrounding Areas. Publishing House Universali, Tbilisi, 380. (in Georgian)

[21] Tvalchrelidze, M., Dekanosidze, N., Sharashenidze, I., et al. (1993) Preliminary Result of Litho-bio-Stratigraphical Studies of Karst Caves' Terrigenous Sediments. Scientific Session, Tbilisi, 87-88. (In Georgian)

[22] Lezhava, Z., Tsikarishvili, K., Bolashvili, N., Asanidze, L. and Chikhradze, N. (2015) 
Preliminary Outcomes of the Eki Mountain Karst-Hydrological and Speleological Study. International Conference: Applied Ecology: Problems and Innovations, Tbilisi, 7-10 May 2015, 89-95.

[23] Tushabramishvili, D., Tvalchrelidze, M., Tushabramishvili, N., et al. (1992) OrtvalaKlde Paleolithic Former Dwelling. Scientific Session of Speleologist, Tbilisi, 11-12. (In Georgian)

[24] Lezhava, Z., Gigineishvili, G., Tabidze, D., et al. (1990) New Data about the Chiatura Plateau Karst-Hydrogeological Peculiarities. Vakhushti Bagrationi Institute of Geography. Final Scientific Session, Tbilisi, 5-7. (In Georgian)

[25] Kalandadze, A. (1969) Tsona Cave Archeological Excavation Preliminary Results. Speleological Second Scientist Session, Tbilisi, 31-36. (In Georgian)

[26] Lubin, V.P. (1960) Lower Paleolithic Monuments of South Ossetia. Materials and Research of the Archeology of the USSR. Vol. 4, ANSSSR, Moscow, 9-78. (In Russian)

[27] Tsereteli, D.V. (1970) On the Geological Dating of the Cultural Remains of Paleolithic Human of the Tsona Cave and Paleogeographic Conditions. Proceedings of Geographical Society of Georgian SSR, Tbilisi. 17-26. (In Russian)

\section{Scientific Research Publishing}

\section{Submit or recommend next manuscript to SCIRP and we will provide best} service for you:

Accepting pre-submission inquiries through Email, Facebook, LinkedIn, Twitter, etc. A wide selection of journals (inclusive of 9 subjects, more than 200 journals)

Providing 24-hour high-quality service

User-friendly online submission system

Fair and swift peer-review system

Efficient typesetting and proofreading procedure

Display of the result of downloads and visits, as well as the number of cited articles Maximum dissemination of your research work

Submit your manuscript at: http://papersubmission.scirp.org/

Or contact ojg@scirp.org 